\title{
Effects of colchicine on the ovine corpus luteum: role of microtubules in the secretion of progesterone
}

\author{
R. T. Gemmell and B. D. Stacy \\ Division of Animal Production, C.S.I.R.O., The Ian Clunies Ross Animal Research Laboratory, \\ Prospect, New South Wales, Australia*
}

\begin{abstract}
Summary. By $4 \mathrm{~h}$ after i.v. injection of ewes at the mid-luteal phase of the oestrous cycle with colchicine $(1 \mathrm{mg} / \mathrm{kg})$, the concentration of progesterone in peripheral plasma was halved while the content of progesterone in luteal tissue was doubled. The ultrastructure of the luteal tissue showed some specific drug-induced changes: microtubules were no longer present and the intracellular transport and secretion of granules associated with progesterone secretion appeared to be inhibited.
\end{abstract}

Microtubules have an important function in the intracellular translocation of cytoplasmic organelles (Malawista, 1968; Gee \& Cross, 1973; Orci et al., 1973). An expression of this function can be seen in many secretory processes in which densely staining granules become associated with microtubules before being transferred to the cell periphery where the granules are secreted by exocytosis. This mechanism of secretion has been described for insulin (Lacy, Howell, Young \& Fink, 1968; Orci, 1974), glucagon (Leclercq-Meyer, Le Marchand \& Malaisse, 1974), catecholamines (Poisner \& Bernstein, 1971) and albumin (Le Marchand, Patzelt, Assimacopoulos-Jeannet, Loten \& Jeanreynaud, 1974). Drugs such as colchicine, which specifically disrupt the microtubular system, have also been shown to interfere with the process of secretion.

There is evidence that progesterone is secreted in granule form by the ovine luteal cell (Gemmell, Stacy \& Thorburn, 1974). Microtubules are also present in the luteal cell but their function in relation to the secretion of progesterone has not been explored. The present work was therefore undertaken with sheep to see whether the effects of colchicine on the structure and function of the luteal cell might help to throw further light on the mechanism of progesterone secretion.

\section{Methods}

Adult Merino ewes were used; there were 10 in the control group used to obtain data on the normal levels of progesterone in luteal tissue at the mid-point of the cycle and 10 in the treatment group. Two of the latter ewes were induced to ovulate by injection with $1000 \mathrm{i} . u$. PMSG. Oestrus in all ewes was detected by daily testing with a vasectomized ram. Near Day 10 of the oestrous cycle the experimental sheep were given a single i.v. injection of colchicine $(1 \mathrm{mg} / \mathrm{kg})$. Blood samples were withdrawn from the jugular vein for progesterone determination (Thorburn \& Schneider, 1972) every $\frac{1}{2} \mathrm{~h}$ for $4 \mathrm{~h}$ after the treatment. The content of progesterone in luteal tissue was determined (Gemmell et al., 1974) $2 \mathrm{~h}$ ( 2 sheep) and $4 \mathrm{~h}$ ( 3 sheep) after colchicine administration. Ovaries from 5 of the treated animals were fixed by intravascular perfusion at 1,2,3 and $4 \mathrm{~h}$; details of fixation and processing of tissue for electron microscopy have been described previously (Gemmell et al., 1974).

\section{Results and discussion}

As shown in Table 1 the concentration of progesterone in peripheral plasma decreased following treatment with colchicine, to about $50 \%$ of the control value by the end of the experiment. Before the colchicine injection, the peripheral plasma progesterone concentrations were 10 and $12 \mathrm{ng} / \mathrm{ml}$ for the 2

*Postal adduress: P.O, Box 239, Blacktown, New South Wales 2148, Australia, 
sheep treated with PMSG and 2-4 ng/ml for the other 8 ewes. The decrease in plasma progesterone was accompanied by an increase in the amount of progesterone in luteal tissue. The mean luteal concentration of progesterone was $20 \mu \mathrm{g} / \mathrm{g}$ luteal tissue in control animals (10 samples) and increased to $26 \mu \mathrm{g} / \mathrm{g} 2 \mathrm{~h}$ after injection ( 2 samples) and to $50 \mu \mathrm{g} / \mathrm{g} 4 \mathrm{~h}$ after injection ( 3 samples).

Table 1. Mean \pm S.E.M. percentage change* in peripheral plasma progesterone concentration of ewes after colchicine injection

\begin{tabular}{lcccccccccc}
\hline & \multicolumn{8}{c}{ Time after injection (h) } \\
\cline { 2 - 11 } & 0 & $\frac{1}{2}$ & 1 & $1 \frac{1}{2}$ & 2 & $2 \frac{1}{2}$ & 3 & $3 \frac{1}{2}$ & 4 \\
\hline $\begin{array}{l}\text { No. of animals } \\
\begin{array}{l}\text { Plasma progesterone } \\
\text { conc. (\%) }\end{array}\end{array}$ & 10 & 6 & 10 & 2 & 8 & 2 & 4 & 1 & 4 \\
\hline
\end{tabular}

* At each sampling time, the \% reduction in progesterone concentration for each animal was determined, and the mean and S.E.M. calculated from all samplings for that time.

At Day 10 of the oestrous cycle in the ewe, the large polyhedral luteal cell in the corpus luteum is characterized by a centrally placed nucleus, numerous Golgi regions, abundant agranular endoplasmic reticulum and mitochondria with the specialized features of steroid-secreting cells (Christensen \& Gillim, 1969) (P1. 1, Figs 1 and 2). Small densely staining granules (0.2 $\mu \mathrm{m}$ diam.) are present in the cytoplasm (Pl. 1, Fig. 1) and they can also be seen in the intercellular space in the process of being secreted by the cell (P1. 1, Figs 1 and 2). The granules may occasionally be observed in close apposition to microtubules (P1. 2, Fig. 3).

By $1 \mathrm{~h}$ after the injection of colchicine there were no gross changes in the appearance of the luteal cells, but the secretion of granules had diminished (P1. 2, Fig. 4) and microtubules were not as prevalent as in control tissue. By $\mathbf{2} \mathbf{h}$ after treatment the agranular endoplasmic reticulum had increased dramatically (Pl. 3, Fig. 5), there were no microtubules and the production and secretion of granules appeared to have ceased. Irregularly shaped bodies, also seen in close proximity to the plasma membrane (Pl. 3, Fig. 6), were present near the Golgi regions where the granules had been. A similar

\section{EXPLANATION OF PLATES}

PLATE 1

Fig. 1. A luteal cell of a ewe on the 10th day of the oestrous cycle. There are densely staining granules within the cell and others in the process of being secreted (arrowed). $\times 9000$.

Fig. 2. Profuse numbers of densely staining granules being secreted from luteal cells at Day 10 of the oestrous cycle of sheep. $\times 18,000$.

\section{PLATE 2}

Fig. 3. A high magnification of a region of a luteal cell of a ewe on the 10 th day of the oestrous cycle. A microtubule is shown (arrowed) passing close to a densely staining granule. $\times 56,000$.

Fig. 4. An ovine luteal cell $1 \mathrm{~h}$ after colchicine treatment. Granule secretion is no longer discernible. $\times 22,500$.

\section{PLATE 3}

Fig. 5. A luteal cell $2 \mathrm{~h}$ after colchicine treatment. Agranular endoplasmic reticulum (AER), is unusually prominent but densely staining granules are no longer observed either in the cytoplasm or in the intercellular space. Irregularly shaped bodies of densely staining material (arrowed) are present in the Golgi region. $\times 7000$.

Fig. 6. Higher magnification of part of an ovine luteal cell $2 \mathrm{~h}$ after colchicine treatment. Densely staining bodies (arrowed) are present at the periphery of the cell and in the Golgi region (G). $\times 26,000$.

\section{PLATE 4}

Fig. 7. A luteal cell of a ewe $4 \mathrm{~h}$ after colchicine treatment. Densely staining, irregularly shaped bodies (arrowed) can be seen in the Golgi region below the nucleus. $\times 8000$.

Fig. 8. Higher magnification of the Golgi region in Fig. 7 to illustrate the numerous densely staining bodies of irregular shape. $\times 26,000$. 


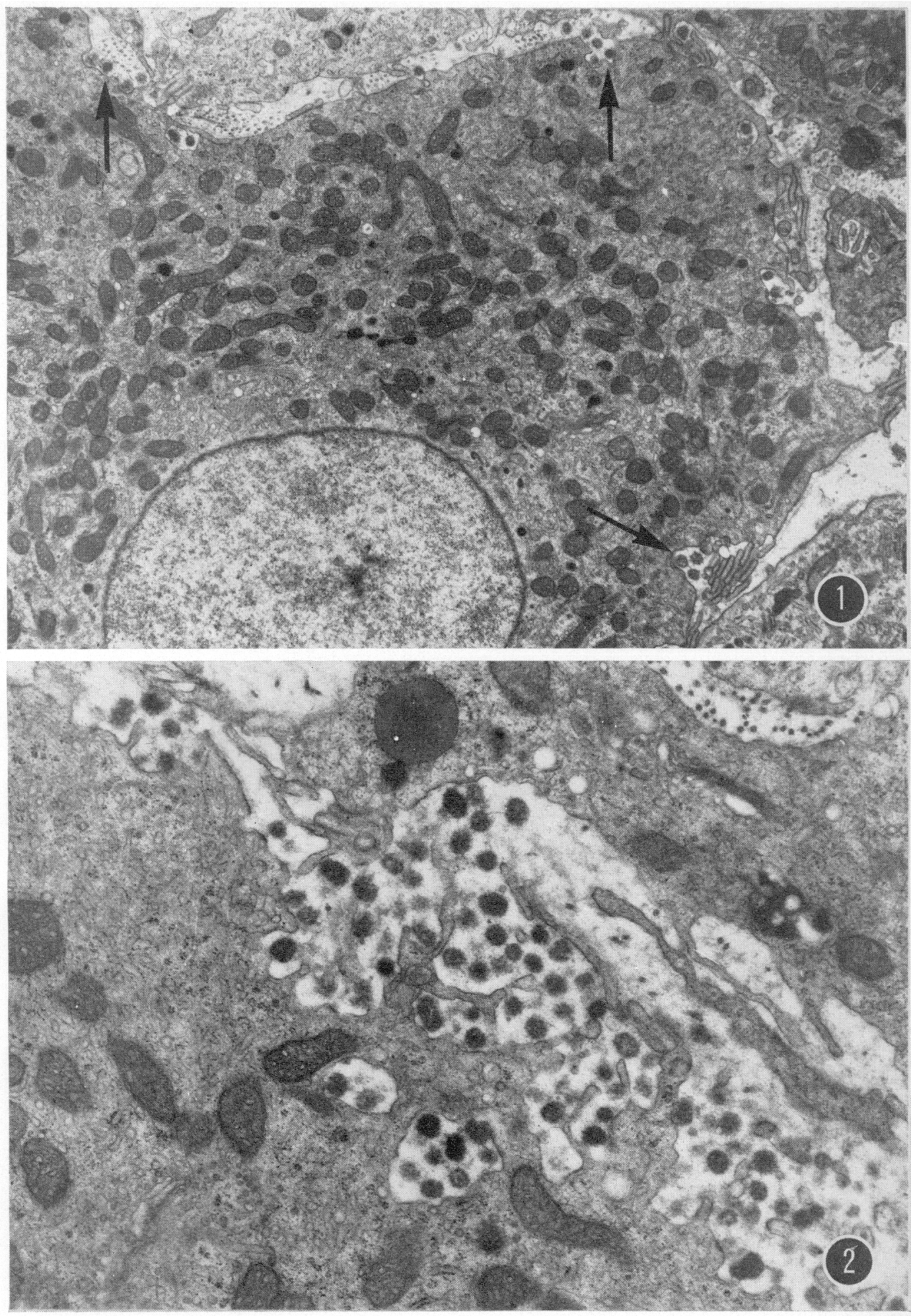




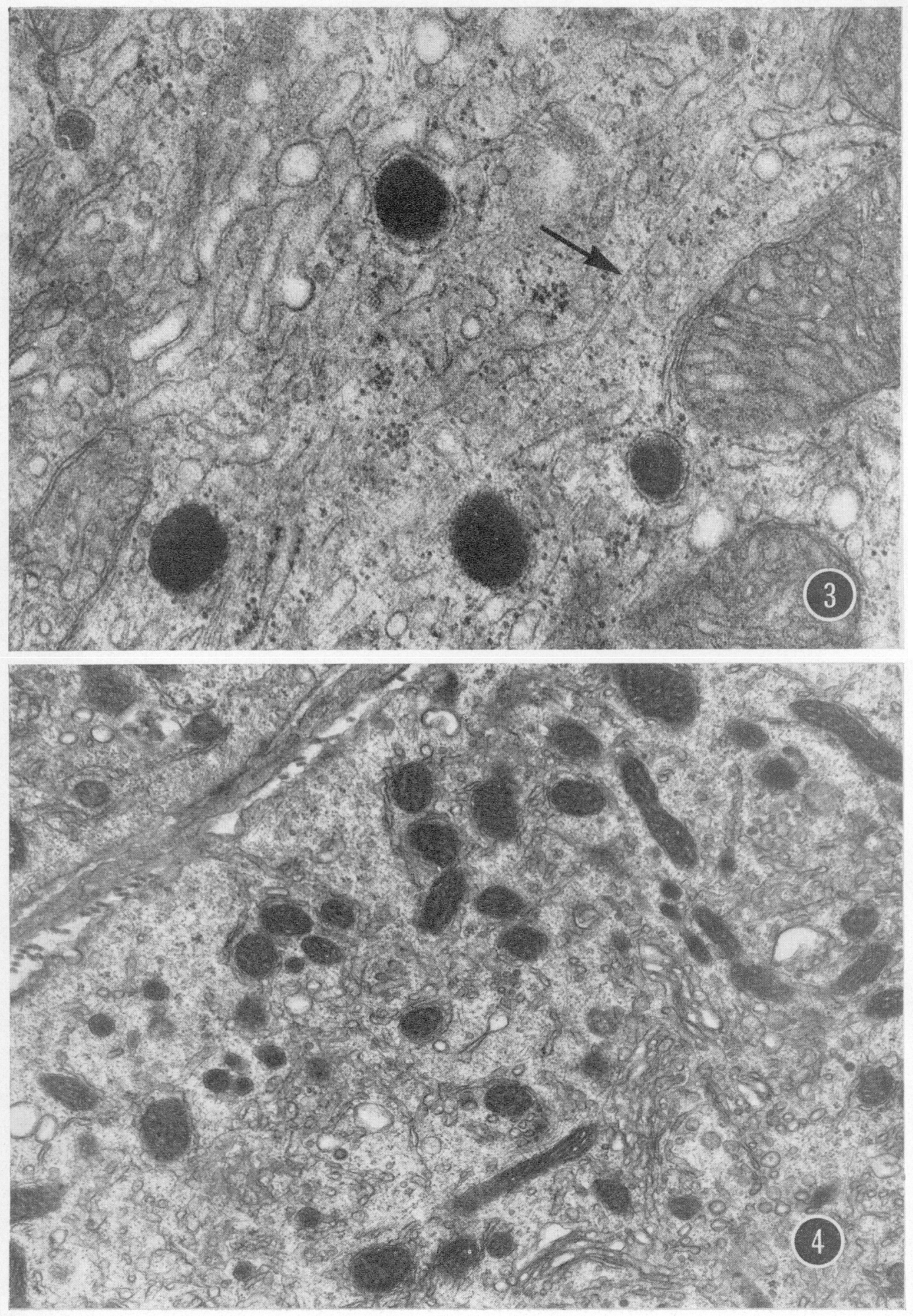



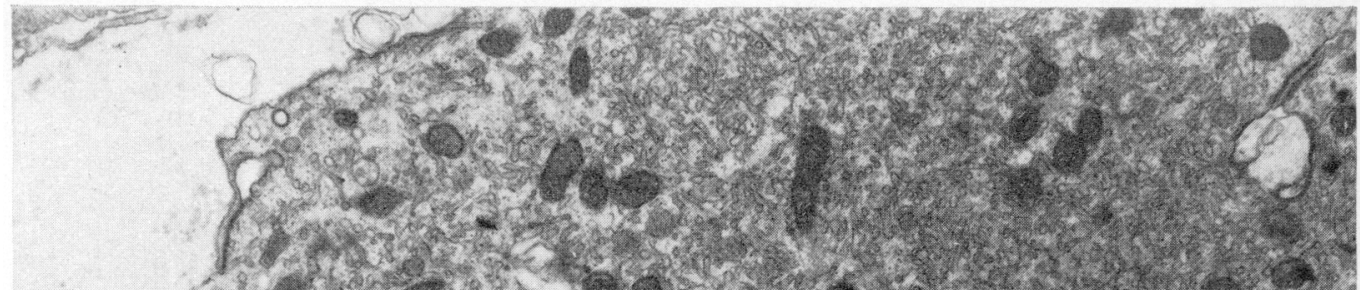
Br. (2)

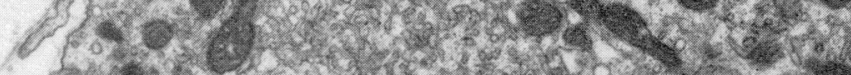

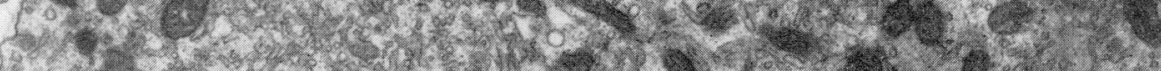

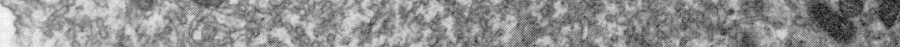

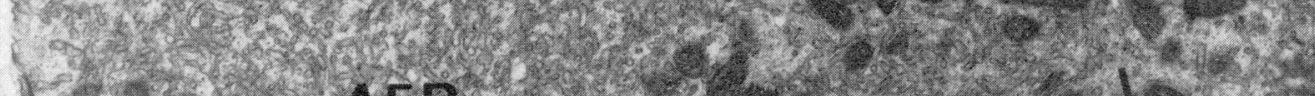

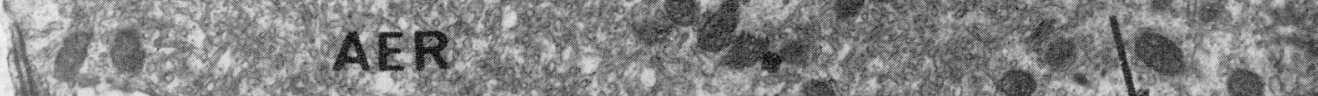

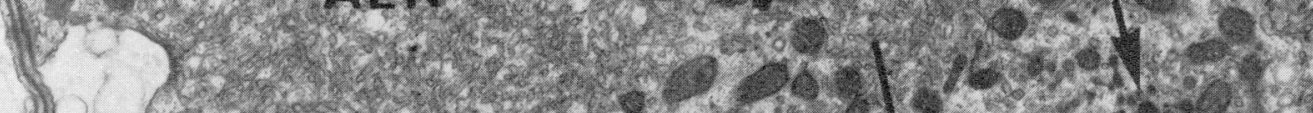

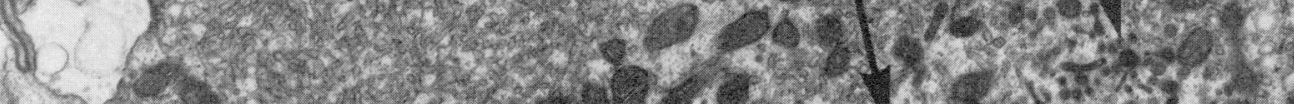

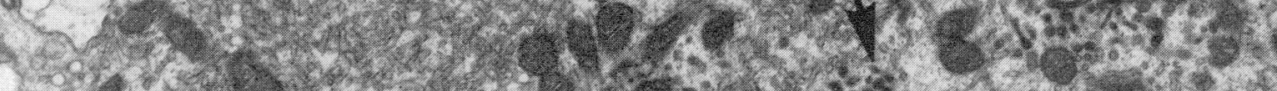

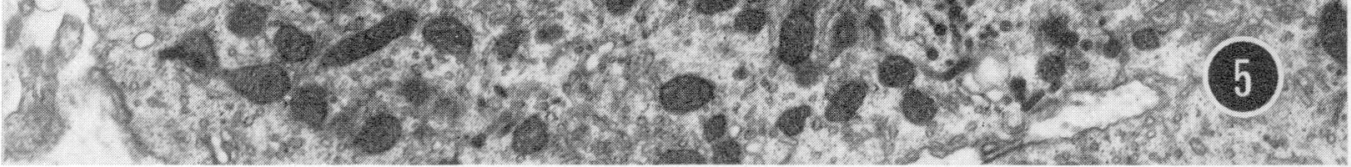

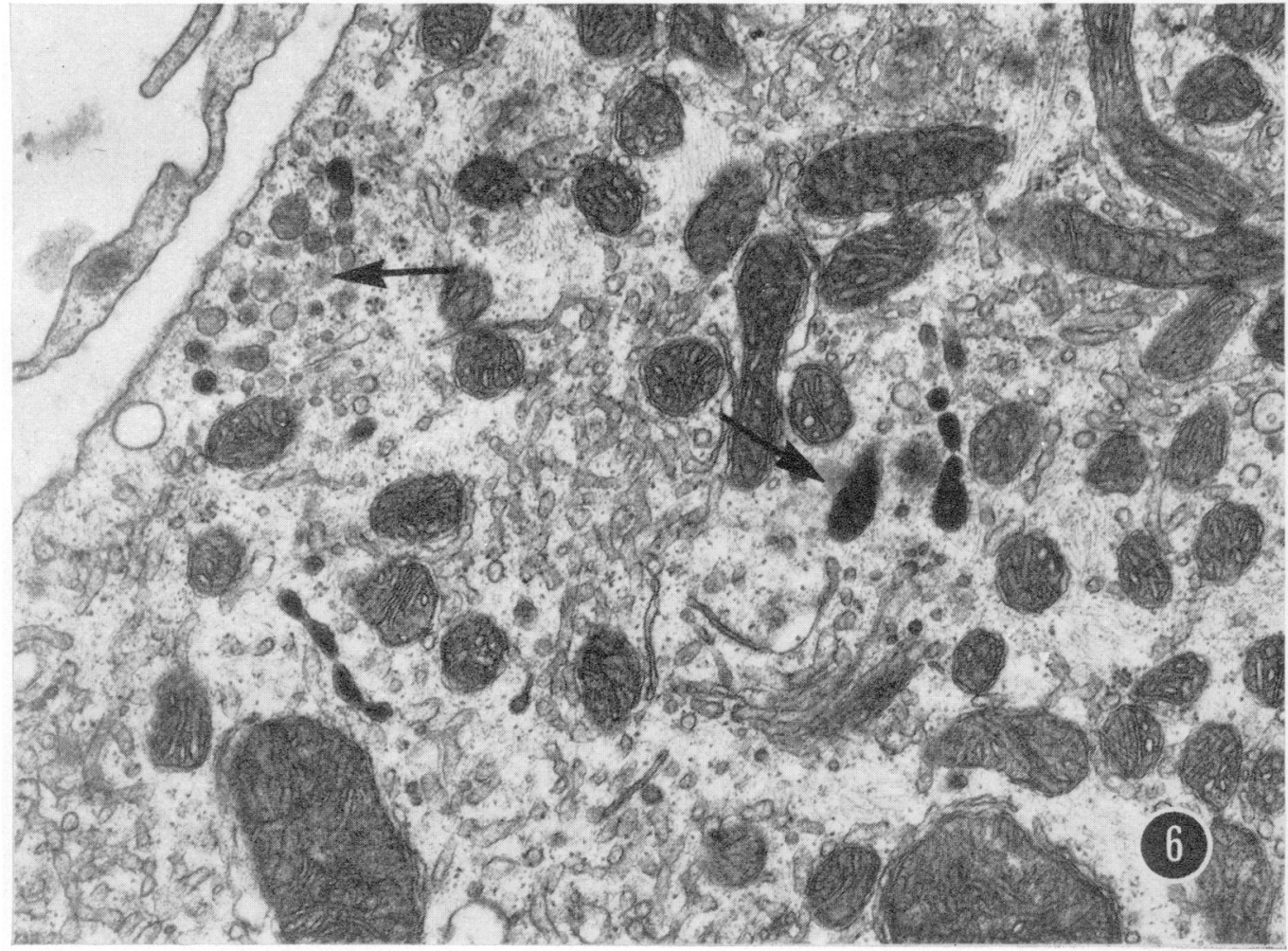



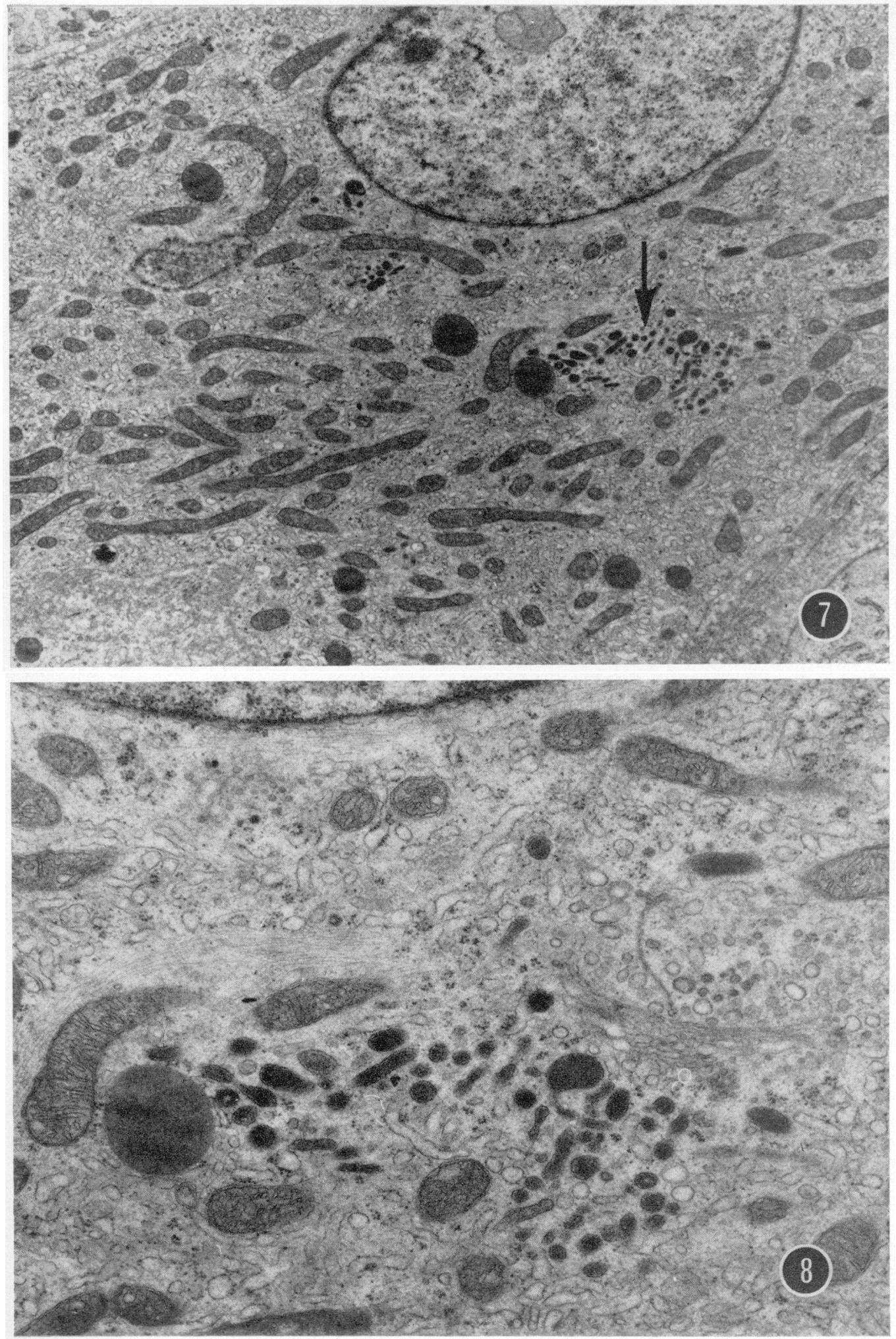
morphological picture was seen at $4 \mathrm{~h}$ : agranular endoplasmic reticulum was profuse and the irregularly shaped bodies, containing densely staining material, were present mainly in the Golgi regions (PI. 4, Figs 7 and 8). Microtubules were not observed in the specimens taken at 2 and $4 \mathrm{~h}$ after treatment with colchicine.

Colchicine treatment inhibited the secretion of progesterone by the ovine corpus luteum and produced specific derangements in the fine structure of the luteal cell. The nature of these druginduced changes is compatible with the known action of colchicine on other organs, and the results add further support to the recent report that progesterone is secreted in granule form by the ovine luteal cell (Gemmell et al., 1974). Colchicine has been observed to cause disruption of microtubules in cells of the liver, pancreas and parathyroid gland (Stein, Sanger \& Stein, 1974; Orci, 1974; Reaven \& Reaven, 1975), and inhibition of secretion from the glands. A similar impairment of the microtubular assembly was seen in the present studies of luteal cells from colchicine-treated ewes, and the normal pattern of granule formation was also affected. The presence of the irregularly shaped bodies of densely staining material when evidence of the secretion of the densely staining granules believed to contain progesterone (Gemmell et al., 1974) could no longer be detected suggests that the normal process for packaging and transfer of granules was defective.

The suppression of progesterone secretion cannot be attributed to decreased hormone synthesis. Steroidogenic mechanisms continued to function after colchicine treatment as shown by the increase in the progesterone content of luteal tissue. There was no marked increase in the number of granules or irregular bodies $4 \mathrm{~h}$ after treatment, suggesting that the excess tissue progesterone was not stored in these organelles but was perhaps associated with the increased amount of agranular endoplasmic reticulum which is believed to be the site of conversion of pregnenolone to progesterone (Christensen \& Gillim, 1969). The lack of effect of colchicine on the progesterone biosynthesis is in keeping with previous findings that the drug does not interfere with insulin synthesis in the pancreatic $\beta$ cell (Lacy et al., 1968) or with albumin synthesis in the hepatocyte (Le Marchand et al., 1974).

\section{References}

Christensen, A.K. \& Gillim, S.M. (1969) The correlation of the fine structure and function in steroidsecreting cells, with emphasis on those of the gonads. In The Gonads, pp. 415-488. Ed. K. W. Kerns. North Holland, Amsterdam.

GeE, J.B.L. \& CROss, C.E. (1973) Drugs affecting phagocytosis and pinocytosis. In Fundamentals of Cell Pharmcology, pp. 349-372. Ed. S. Dikstein. Charles C. Thomas, Springfield, Illinois.

Gemmell, R.T., Stacy, B.D. \& Thorburn, G.D. (1974) Ultrastructural study of secretory granules in the corpus luteum of the sheep during the estrous cycle. Biol. Reprod. 11, 447-462.

LACY, P.E., Howell, S.L., Young, D.A. \& FinK, C.J. (1968) New hypothesis of insulin secretion. Nature, Lond.219, 1177-1179.

Leclerq-Meyer, V., Le Marchand, J. \& Malaisse, W.J. (1974) Possible role of a microtubular-microfilamentous system in glucagon secretion. Diabetologia 10, 215-224.

Malawista, S.E. (1968) Colchicine: a common mechanism for its anti-inflammatory and anti-mitotic effects. Arthritis Rheum. 11, 191-197.

Le Marchand, Y., Patzelt, C., AssimacopoulosJEANNET, F., Loten, E.H. \& JeAnREYNAUd, B. (1974) Evidence for a role of the microtubular system in the secretion of newly synthesized albumin and other proteins by the liver. J. Clin. Invest. 53, 1512-1517.

ORCI, L. (1974) A portrait of the pancreatic beta cell. Diabetologia 10, 163-187.

Orci, L., Le Marchand, Y., Singh, A., AssimacoPoulos-Jeannet, F., Rouiller, Ch. \& JeanreyNAUD, B. (1973) Role of microtubules in lipoprotein secretion by the liver. Nature, Lond. 244, 30-32.

Poisner, A.M. \& Bernstein, J. (1971) A possible role o microtubules in catecholamine release from the adrenal medulla: effect of colchicine, vinca alkaloids and deuterium oxide. J. Pharmac. exp. Ther. 177, 102-109.

Reaven, E.P. \& Reaven, G.M. (1975) A quantitative ultrastructural study of microtubule content and secretory granule accumulation in parathyroid glands of phosphate- and colchicine-treated rats. J. clin. Invest. 56, 49-55.

Stein, O., Sanger, L. \& Stein, Y. (1974) Colchicineinduced inhibition of lipoprotein and protein secretion into the serum and lack of interference with secretion of biliary phospholipids and cholesterol by rat liver in vivo. J. Cell Biol. 62, 90-103.

Thorburn, G.D. \& SchneIder, W. (1972) The progesterone concentration in the plasma of the goat during the oestrous cycle and pregnancy. $J$. Endocr. 52, 23-36. 